\title{
Association of CD247 (CD3乙) gene polymorphisms with T1D and AITD in the population of northern Sweden
}

\author{
Dan Holmberg ${ }^{1,2}$, Karin Ruikka ${ }^{3}$, Petter Lindgren', Mats Eliasson ${ }^{3,4}$ and Sofia Mayans ${ }^{1,5^{*}}$
}

\begin{abstract}
Background: T1D and AITD are autoimmune disorders commonly occurring in the same family and even in the same individual. The genetic contribution to these disorders is complex making uncovering of susceptibility genes very challenging. The general aim of this study was to identify loci and genes contributing to T1D/AITD susceptibility. Our strategy was to perform linkage and association studies in the relatively genetically homogenous population of northern Sweden. We performed a GWLS to find genomic regions linked to T1D/AITD in families from northern Sweden and we performed an association study in the families to test for association between T1D/ AITD and variants in previously published candidate genes as well as a novel candidate gene, CD247.

Methods: DNA prepared from 459 individuals was used to perform a linkage and an association study. The ABI PRISM Linkage Mapping Set V2.5MD10 was employed for an initial 10-cM GWLS, and additional markers were added for fine mapping. Merlin was used for linkage calculations. For the association analysis, a GoldenGate Custom Panel from Illumina containing 79 SNPs of interest was used and FBAT was used for association calculations.

Results: Our study revealed linkage to two previously identified chromosomal regions, 4q25 and 6p22, as well as to a novel chromosomal region, 1q23. The association study replicated association to PTPN22, HLA-DRB1, INS, IFIH1, CTLA4 and C12orf30. Evidence in favor of association was also found for SNPs in the novel susceptibility gene CD247.

Conclusions: Several risk loci for T1D/AITD identified in published association studies were replicated in a family material, of modest size, from northern Sweden. This provides evidence that these loci confer disease susceptibility in this population and emphasizes that small to intermediate sized family studies in this population can be used in a cost-effective manner for the search of genes involved in complex diseases. The linkage study revealed a chromosomal region in which a novel T1D/AITD susceptibility gene, CD247, is located. The association study showed association between T1D/AITD and several variants in this gene. These results suggests that common susceptibility genes act in concert with variants of CD247 to generate genetic risk for T1D/AITD in this population.
\end{abstract}

Keywords: Linkage, Association, Family, Type 1 diabetes, Autoimmune thyroid disease

\section{Background}

Type 1 diabetes mellitus (T1D) and autoimmune thyroid disease (AITD) are autoimmune disorders under complex genetic control [1]. There is a well-known association between T1D and AITD, and both diseases often occur in the same family and even in the same individual,

\footnotetext{
*Correspondence: sofia.mayans@umu.se

'Department of Medical Biosciences - Medical Genetics, Umeå University, SE-901 85 Umeå, Sweden

${ }^{5}$ Department of Clinical Microbiology, Division of Immunology, Umeå

University, Building 6C, SE-90185 Umeå, Sweden

Full list of author information is available at the end of the article
}

suggesting common genetic causes [1-4]. Several genome-wide linkage scans (GWLS) have been performed to search for genes contributing to T1D [5-10], but to date, no GWLS has been performed on the population of northern Sweden. An internal expansion of the northern Swedish population, together with a low frequency of immigration and a high frequency of consanguineous marriages has resulted in a relatively genetically homogeneous population [11-13]. This genetic composition coupled with other factors, such as the Swedish healthcare system and detailed church records, have enabled the 
successful use of this population in genetic studies of complex diseases, such as T1D [14, 15], type 2 diabetes $[16,17]$ and stroke [18]. Genome-wide association (GWA) studies have revealed several risk factor genes/loci for T1D, AITD and a number of other diseases [19-25]. These studies have found convincing evidence of associations of several loci with T1D: HLA class II genes on chromosome 6p21, INS on $11 \mathrm{p} 15$, CTLA4 on $2 \mathrm{q} 33$, PTPN22 on $1 \mathrm{p} 13$, the $I L 2 R \alpha$ region on 10p15 and the IFIH1 region on 2q24. Multiple novel chromosomal regions, including 12q13, 12q24, 16p13 and 18p11, have been associated with T1D in both familybased studies and case-control cohorts [19, 21, 23, 26]. Several of the identified risk genes are immunoregulatory in nature, and many of these genes and/or associated biological pathways have also been observed to overlap with findings from animal models of T1D, notably the nonobese diabetic (NOD) mouse model.

Both T1D and AITD develop through a process mediated by $\mathrm{T}$ lymphocytes [1] and signaling through the $\mathrm{T}$ cell receptor (TCR)/CD3 complex is required for the activation of T cells. The CD3 complex consists of two CD3r, one $\mathrm{CD} 3 \gamma$, one $\mathrm{CD} 3 \delta$ and two $\mathrm{CD} 3 \zeta$ subunits. Phosphorylation of immunoreceptor tyrosine-based activation motifs (ITAMs) in the CD3 complex is one of the earliest detectable events occurring after TCR engagement [27, 28]. Several of the genes associated to T1D and/or AITD, such as PTPN22, CTLA4 and IL2/IL2RA are important for T cell activation, regulation and function [29-32].

In this study, linkage and association analyses of multiplex families from northern Sweden have been employed to find genetic regions and variants contributing to T1D/ AITD in the families. We report linkage to T1D/AITD for three chromosomal region and we replicate the previously reported association for T1D/AITD with single nucleotide polymorphisms (SNPs) in PTPN22, HLA-DRB1, INS, IFIH1, CTLA4 and C12orf30 [21, 23, 24, 33, 34]. We also report association to T1D/AITD for SNPs in the novel susceptibility gene $C D 247$.

\section{Methods}

\section{Families}

The initial 10-centimorgan (cM) GWLS included a total of 42 families with 184 family members (54 patients with T1D, 48 patients with AITD, 12 patients with both disorders and 70 unaffected family members) from northern Sweden. Population-based registers, the autoimmune disease register at Sunderby Hospital and the Swedish childhood diabetes registry [35] were used to identify T1D or AITD probands below the age of 50. First-degree relatives with T1D or AITD were then identified, and diabetes diagnoses were confirmed by examining the medical records of both probands and relatives. Genotyping of regions with an initial logarithm of odds (LOD) score higher than 1.5 was further performed in 275 individuals
(69 patients with T1D, 62 patients with AITD, 8 patients with both disorders 136 unaffected family members) from an additional 55 families. In a family-based association study, all 459 individuals from the 97 families were genotyped and analyzed. This study was conducted with the approval of the regional ethical review board, and informed consent was obtained from all participants. Clinical characteristics of the study material can be found in Additional file 1: Tables S1 and S2.

\section{DNA extraction}

Genomic DNA was prepared from buffy coat samples using the FlexiGene DNA Kit (Qiagen, Venlo, the Netherlands). DNA extraction was performed according to the manufacturer's instructions.

\section{Genome-wide scan}

An ABI linkage panel set with an average spacing of 10 cM (ABI PRISM Linkage Mapping Set v2.5MD10, Applied Biosystems, Foster City, CA, USA) was used for the initial 10-cM GWLS. PCR products were analyzed on an ABI PRISM 3730 DNA Sequencer, and genotypes were analyzed using GeneMapper v3.7 (Applied Biosystems, Foster City, CA, USA). The largest gap in the initial GWLS was $14.7 \mathrm{cM}$. Additional markers from the ABI PRISM Linkage Mapping 5-cM Set, and markers ordered from DNA Technology (Aarhus, Denmark) were typed on chromosomes 1, 4 and 6 in the regions with an initial LOD score higher than 1.5.

\section{SNP genotyping}

A GoldenGate Custom Panel containing 79 SNPs of interest (Additional file 1: Table S3) was purchased from Illumina (San Diego, CA), and genotyping was performed according to the manufacturer's instructions. SNPs were analyzed using Illumina Beadstation 500GX, and genotypes were analyzed using BeadStudio v.3 (Illumina, San Diego, CA). For each SNP, $8.5 \%$ of the total samples were run in duplicate, and $100 \%$ concordance was observed between duplicates. A genotyping success rate ranging from $79 \%$ to $99 \%$ was obtained for the SNPs under investigation (Additional file 1: Table S3).

\section{Statistics}

For the GWLS, model-free multipoint linkage analysis was performed using Merlin, and allele frequencies were estimated from all genotyped individuals [36]. Three models were used for the statistical calculations. In disease model 1, individuals with T1D were set as affected. In disease model 2, individuals with T1D, individuals with AITD and individuals with both diseases were set as affected. In disease model 3, individuals with AITD were set as affected. Association analysis in the familybased material was performed using FBAT v2.0.4Q 
(http://www.hsph.harvard.edu/fbat/default.html), which is a software package used for computing Family Based tests of Association. $P$-values were not corrected for multiple comparisons. A SNP with a $p$-value $<0.05$ was considered associated to T1D/AITD. The distribution of alleles in the SNPs under investigation did not deviate significantly from Hardy-Weinberg equilibrium in the control group.

\section{Results}

In the first family recruitment, 42 families were identified, and 184 individual samples (54 patients with T1D, 48 patients with AITD, 12 patients with both disorders and 70 unaffected family members) were collected to be included in a 10-cM GWLS. The initial linkage analysis revealed allele-sharing LOD scores $>1.5$ (arbitrary chosen cut-off) at three locations: 1q23 (LOD $=1.99$ at marker D1S452), 4q26 (LOD $=1.92$ at marker D4S402) and 6p21 (LOD = 1.78 at marker D6S1549) (Fig. 1). Fine mapping of the three regions of interest and the addition of 275 individuals (69 patients with T1D, 62 patients with AITD, 8 patients with both disorders and 136 unaffected family members) from 55 new families increased the LOD score at $4 \mathrm{q} 25(\mathrm{LOD}=1.97$ at marker
D4S1616) and 6p22 (LOD = 3.26 at marker D6S422) and decreased the LOD score slightly at $1 \mathrm{q} 23(\mathrm{LOD}=1.77$ at marker D1S484) (Fig. 2).

SNPs chosen for the association study were selected based on the results from our GWLS in combination with SNPs associated to T1D/AITD in previously published GWA studies [19-23]. 79 SNPs, 42 previously published associated SNPs and 37 SNPs within the novel susceptibility gene, $C D 247$, were selected to be included on an Illumina GoldenGate Custom Panel (Additional file 1: Table S3). DNA from 459 individuals, including 123 patients with T1D, 110 patients with AITD, 20 patients with both disorders and 206 healthy individuals from 97 families, were genotyped using this panel. SNPs were tested for deviation from Hardy-Weinberg equilibrium in the control group using Haploview 3.2 [37]. Of the 79 SNPs included in the panel, 13 were associated (nominal $p<0.05)$ with T1D, while 6 were associated with AITD (nominal $p<0.05$ ) (Table 1). Evidence in favor of association with T1D was obtained for SNPs in PTPN22 $\left(\mathrm{rs} 6679677 \mathrm{p}=4.5 \times 10^{-4}, \mathrm{rs} 2476601 \mathrm{p}=4.5 \times 10^{-4}\right), C D 247$ (rs6668182 $p=0.007, \mathrm{rs} 2988276 p=3.8 \times 10^{-5}, \mathrm{rs} 7523351$ $p=0.012, \operatorname{rs} 10918695 p=0.006, \quad r s 12144621 p=0.036$, rs863455 $p=0.025, \quad$ rs704852 $p=0.029), \quad H L A-D R B 1$

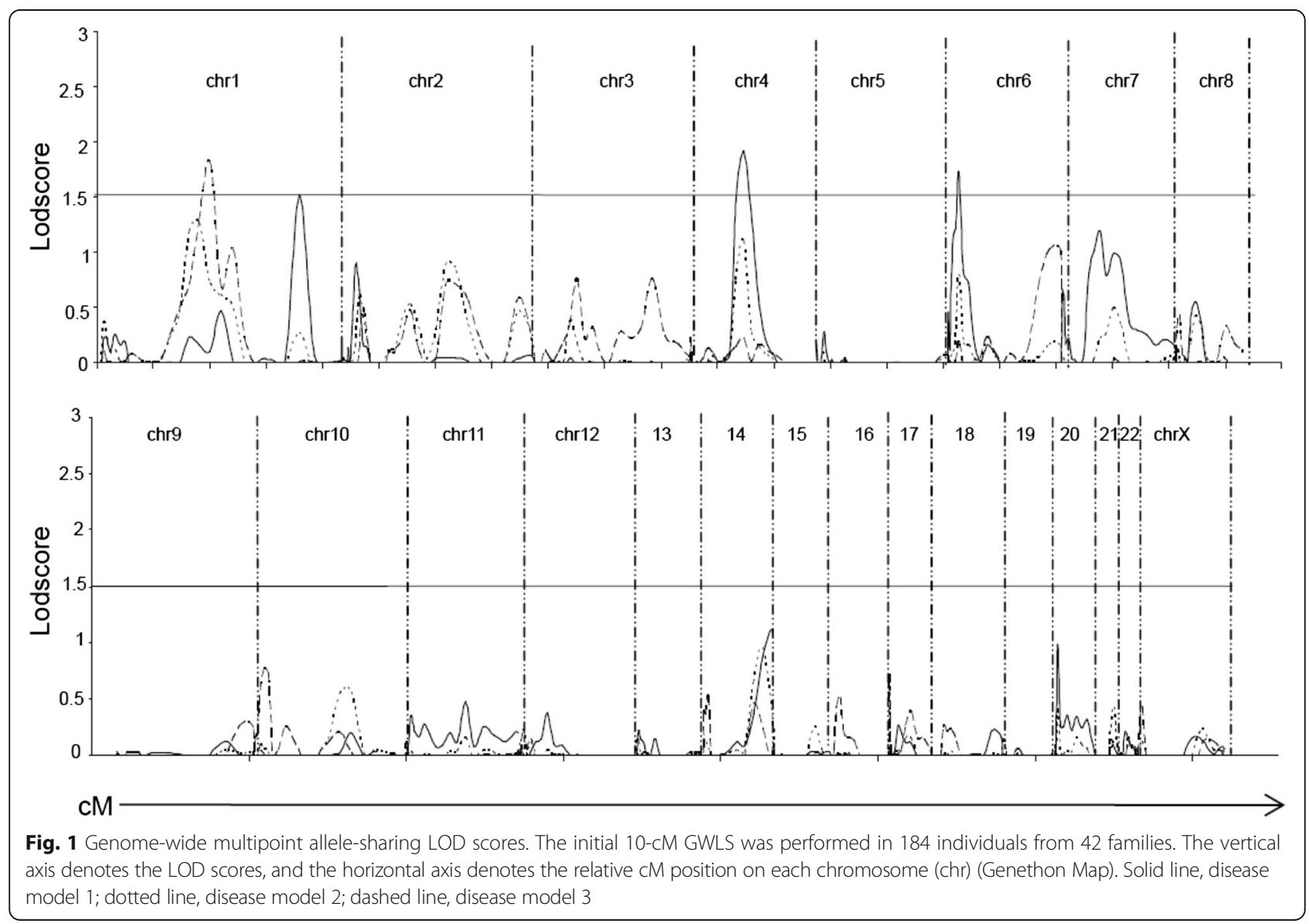




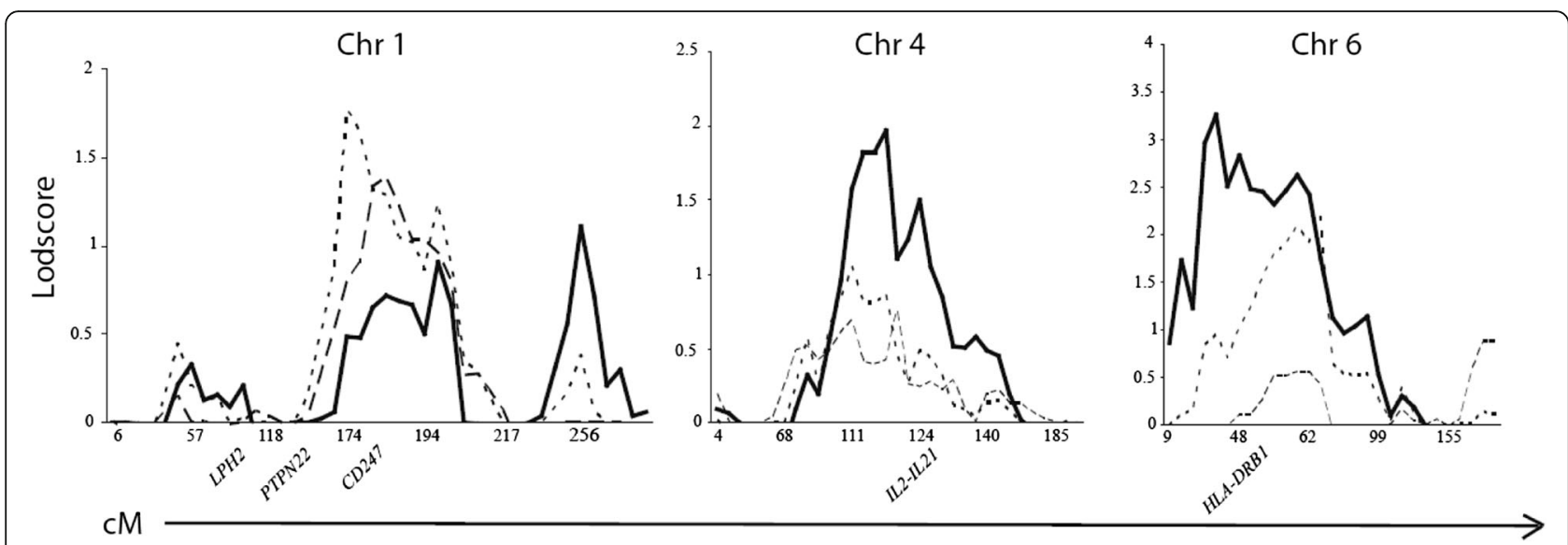

Fig. 2 Multipoint allele-sharing LOD scores after fine mapping. Multipoint allele-sharing LOD scores after fine mapping of regions with an LOD score $>1.5$ in the initial 10-cM GWLS and with the addition of 275 new individuals. The vertical axis denotes LOD scores, and the horizontal axis denotes relative $\mathrm{CM}$ position (Genethon map). Genetic location of genes included in the association study is shown on the horizontal axis. Solid line, disease model 1; dotted line, disease model 2; dashed line, disease model 3

(rs9270986 $\left.\mathrm{p}=1.8 \times 10^{-6}\right)$ and INS (rs1004446 $p=0.011$, rs6356 $p=0.020$, rs7111341 $p=0.021)$. Evidence in favor of association with AITD was obtained for SNPs in CD247 (rs17534481 $p=0.018, \operatorname{rs} 12095738 p=0.022$ ), IFIH1 (rs1990760 $p=0.032)$, CTLA4 (rs3087243 $p=$ 0.039), INS (rs6356 $p=0.014)$ and C12orf30

Table 1 SNPs showing association to TID or AITD in the family material from northern Sweden

\begin{tabular}{|c|c|c|c|c|}
\hline Disease & Chr & SNP & Gene & $p$-value \\
\hline $\mathrm{T1D}$ & $1 \mathrm{p} 13$ & rs6679677 & PTPN22 & $4.5 \times 10^{-4}$ \\
\hline $\mathrm{T} 1 \mathrm{D}$ & $1 \mathrm{p} 13$ & rs2476601 & PTPN22 & $4.5 \times 10^{-4}$ \\
\hline $\mathrm{T} 1 \mathrm{D}$ & $1 q 24$ & rs6668182 & CD247 & 0.007 \\
\hline T1D & $1 q 24$ & rs2988276 & CD247 & $3.8 \times 10^{-5}$ \\
\hline T1D & $1 \mathrm{q} 24$ & rs7523351 & CD247 & 0.012 \\
\hline T1D & $1 q 24$ & rs10918695 & CD247 & 0.006 \\
\hline T1D & $1 \mathrm{q} 24$ & rs12144621 & CD247 & 0.036 \\
\hline T1D & $1 q 24$ & rs863455 & CD247 & 0.025 \\
\hline $\mathrm{T} 1 \mathrm{D}$ & $1 q 24$ & rs704852 & CD247 & 0.029 \\
\hline T1D & $6 p 21$ & rs9270986 & HLA-DRB1 & $1.8 \times 10^{-6}$ \\
\hline T1D & $11 p 15$ & rs1004446 & INS & 0.011 \\
\hline T1D & $11 \mathrm{p} 15$ & rs6356 & INS & 0.020 \\
\hline $\mathrm{T} 1 \mathrm{D}$ & $11 p 15$ & rs7111341 & INS & 0.021 \\
\hline AITD & $1 q 24$ & rs17534481 & CD247 & 0.018 \\
\hline AITD & $1 q 24$ & rs12095738 & CD247 & 0.022 \\
\hline AITD & $2 q 24$ & rs1990760 & $\mathrm{IFIH} 1$ & 0.032 \\
\hline AITD & $2 q 33$ & rs3087243 & CTLA4 & 0.039 \\
\hline AITD & $11 p 15$ & rs6356 & INS & 0.014 \\
\hline AITD & $12 q 24$ & rs17696736 & C12orf30 & 0.032 \\
\hline
\end{tabular}

An association ( $p$-value $<0.05$ ) was found for 19 of the 79 SNPs on the GoldenGate Custom Panel with T1D or AITD using the family based association test (FBAT) (http://www.hsph.harvard.edu/fbat/default.html). $P$-values were not corrected for multiple testing (rs17696736 $p=0.032) . P$-values were not corrected for multiple testing.

\section{Discussion}

A GWLS and an association study was performed to replicate known T1D/AITD susceptibility loci/variations and to screen for novel loci in a multiplex family panel, which included family members affected by T1D and/or AITD, from northern Sweden. The AITD patient material in this study included both Graves' disease (GD) and Hashimoto's thyroid (HT) disease patients. Due to the aim of this study we did not attempted to analyze HT and GD as separate groups limiting the analysis to signals common to the two main groups included in the AITD group.

The initial linkage analysis revealed a LOD score $>1.5$ in three regions on chromosomes 1q23, 4q25 and 6p21. The one-lod-drop region on chromosome 4 (4q23-4q27) harbors 264 genes (http://www.ncbi.nlm.nih.gov/projects/ mapview) including the previously published susceptibility genes IL2/IL21 [23, 38]. The one- lod-drop region on chromosome 6 (6p24-6p12) contains 1247 genes including the HLA genes and the one-lod-drop region on chromosome 1 (1q13-1q25) harbors 1378 genes including one very interesting novel candidate gene, $C D 247$.

Next we performed an association analysis to replicate previously published associations as well as to elucidate if there was an association between variants in CD247 and T1D/AITD. The follow-up association analysis confirmed associations with T1D for variants in PTPN22, CD247, HLA and INS and associations with AITD for variants in CD247, IFIH1, CTLA4, INS and C12orf30 with nominal $p$-values $<0.05$. $P$-values were not corrected for multiple testing. As expected, the most robust evidence of association was found for SNPs at the HLA- 
$D R B 1$ locus on chromosome 6, with rs9270986 displaying the lowest $\mathrm{p}$-value $\left(p=1.8 \times 10^{-6}\right)$. After this association, the most robust evidence in favor of association was unexpectedly observed for rs2988276 in $C D 247$ on chromosome $1\left(p=3.8 \times 10^{-5}\right)$.

Variants in PTPN22, HLA-DRB1, INS, IFIH1, CTLA4 and C12orf30 have previously been associated with T1D $[21,23,24,33]$ and variants in most of the above genes have been associated to AITD [4, 14, 34, 39-42] and several other disorders [43-48]. No previous study has shown association between T1D/AITD and CD247, but variants in the gene have been associated with systemic lupus erythematosus (SLE) [49-52], rheumatoid arthritis (RA) [53] and systemic sclerosis [54].

CD247 codes for $\mathrm{CD} 3 \zeta$, which is a component of the TCR/CD3 signaling complex on $\mathrm{T}$ cells, and tyrosine phosphorylation of $\mathrm{CD} 3 \zeta$ is one of the first events occurring after TCR engagement $[27,28]$. The $\mathrm{CD} 3 \zeta$ subunit functions as an amplifier of TCR signaling and is also essential for efficient surface expression of the TCR/CD3 complex $[55,56]$. Upon TCR engagement, CD8/CD4 delivers Lck to the CD3 complex, which leads to phos-

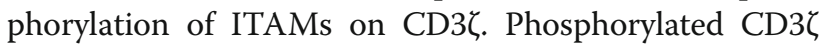
acts as a docking site for Zap-70, which in turn, leads to the phosphorylation of Zap-70. Phosphorylated Zap-70 phosphorylates LAT, leading to downstream signaling (reviewed in [57]). ITAM-mediated signal amplification has been implicated as an important factor in the selection of the mature T-cell repertoire. Positive and negative selection in the thymus is impaired in $\mathrm{CD} 3 \zeta$-deficient mice reconstituted with transgenes encoding $\mathrm{CD} 3 \zeta$ with mutated ITAMs. The requirement for ITAM-mediated signal amplification is most evident in the positive selection of $\mathrm{T}$ cells showing weak TCR-ligand interactions (reviewed in [58]). Holst et al. demonstrated that mice with reduced ITAMs in the TCR/CD3 complex develop a multi-organ autoimmune disease caused by a breakdown in central tolerance [59].

We have previously identified $C d 247$ as a candidate susceptibility gene in murine T1D $[60,61]$ and we found that the NOD allele of $C d 247$ confers impaired T cell activation, resulting in altered cytokine expression patterns, reduced proliferation and deficient CTLA-4 expression compared to the C57BL/6 (B6) allele of Cd247 [60]. Altered expression and function of CD3 has also been implicated in autoimmune disorders, such as SLE $[49,62]$ and RA [63]. We did not find any association between T1D/AITD and variants in IL2/IL21 despite the linkage peak observed in the 4q27 region. One possible explanation for this is that the linkage to T1D/AITD found in the region is caused by other genes or variants than the ones used in our association study.

One limitation of the current study is the relative modest size of the family-based materials employed.
Genome-wide associations can be due to spurious causes, especially heterogeneity/population stratification.

\section{Conclusion}

The fact that we have found association to T1D/AITD for five (PTPN22, IFIH1, CTLA4, INS and C12orf30) previously reported non-HLA genes as well as a novel susceptibility gene, $C D 247$, supports the role for familybased studies in the search for genes involved in complex diseases. The results underpin the notion that the population of northern Sweden is well suited to the detection of genes involved in complex diseases. The use of our more restricted patient material, compared to other materials used in published GWA studies, enables the discovery of disease associated genes in a more cost effective manner and shows that our population is capable of detecting general susceptibility genes. The access to a genotyped family material with both affected and non-affected family members will be very important for future functional studies of associated gene variants.

\section{Additional file}

Additional file 1: Table S1. Clinical characteristics of the study material. Table S2. HLA-DQB1 genotypes in the study material. Table S3. SNPS included in the GoldenGate Custom Panel. (PDF 338 kb)

\section{Acknowledgments \\ The authors would like to thank Maria Lindberg at UTCF Umea University for excellent technical assistance. We are grateful to all participants in this study and for the accessibility to The Swedish Childhood Diabetes register co-ordinated by Gisela Dahlquist and Karin Ruikka. \\ Funding \\ This work was supported by grants from the Swedish Research Council-M, the Kempe Foundation, the Norrbotten County Council, the Joint Committee of Country Councils in northern Sweden, the Novo Nordisk Foundation and the Lundberg Foundation.}

\section{Availability of data and materials}

Data for the GWLS can be found at Open Science Framework (https://osf.io/ extf5/). The name of the dataset is "GWS Dataset Holmberg et al.". Data from the association study can be found in Additional file 1: Table S1.

\section{Authors' contributions \\ $\mathrm{DH}$ conceived the study, participated in the design, carried out the experimental work and drafted the manuscript. KR participated in the study design, carried out the experimental work and the drafting of the manuscript. PL participated in the design of the study and performed the statistical analysis. ME participated in the study design and the drafting of the manuscript. SM conceived the study, participated in the design, carried out the experimental work and drafted the manuscript. All authors read and approved the final manuscript.}

\section{Competing interests}

The authors are not aware of any conflict of interest.

Consent for publication

Not applicable.

Ethics approval and consent to participate

This study was approved by the ethics committee in Umeå, Sweden (\#06-088 M). All individuals included in the study signed a consent to participate. 


\section{Author details}

Department of Medical Biosciences - Medical Genetics, Umeå University, SE-901 85 Umeå, Sweden. ${ }^{2}$ EMV, Immunology, BMC, Lund University, SE-221 00 Lund, Sweden. ${ }^{3}$ Department of Medicine, Sunderby Hospital, SE-971 80 Luleå, Sweden. ${ }^{4}$ Department of Public Health and Clinical Medicine, Umeå University, SE-901 85 Umeå, Sweden. ${ }^{5}$ Department of Clinical Microbiology, Division of Immunology, Umeå University, Building 6C, SE-90185 Umeå, Sweden.

Received: 31 May 2016 Accepted: 29 September 2016

Published online: 04 October 2016

\section{References}

1. Levin $L$, Tomer $Y$. The etiology of autoimmune diabetes and thyroiditis: evidence for common genetic susceptibility. Autoimmun Rev. 2003;2(6): 377-86

2. Barker JM. Clinical review: Type 1 diabetes-associated autoimmunity: natural history, genetic associations, and screening. J Clin Endocrinol Metab. 2006; 91(4):1210-7.

3. Jenkins RC, Weetman AP. Disease associations with autoimmune thyroid disease. Thyroid. 2002;12(11):977-88

4. Tomer Y, Dolan LM, Kahaly G, Divers J, D'Agostino Jr RB, Imperatore G, Dabelea D, Marcovina S, Black MH, Pihoker C, et al. Genome wide identification of new genes and pathways in patients with both autoimmune thyroiditis and type 1 diabetes. J Autoimmun. 2015;60:32-9.

5. Davies JL, Kawaguchi Y, Bennett ST, Copeman JB, Cordell HJ, Pritchard LE, Reed PW, Gough SC, Jenkins SC, Palmer SM, et al. A genome-wide search for human type 1 diabetes susceptibility genes. Nature. 1994;371(6493):130-6.

6. Qiao Q, Osterholm AM, He B, Pitkaniemi J, Cordell HJ, Sarti C, Kinnunen L,

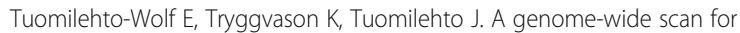
type 1 diabetes susceptibility genes in nuclear families with multiple affected siblings in Finland. BMC Genet. 2007:8:84.

7. Nerup J, Pociot F. A genomewide scan for type 1-diabetes susceptibility in Scandinavian families: identification of new loci with evidence of interactions. Am J Hum Genet. 2001:69(6):1301-13.

8. Concannon P, Erlich HA, Julier C, Morahan G, Nerup J, Pociot F, Todd JA, Rich SS. Type 1 Diabetes Genetics C: Type 1 diabetes: evidence for susceptibility loci from four genome-wide linkage scans in 1,435 multiplex families. Diabetes. 2005;54(10):2995-3001.

9. Morahan G, Mehta M, James I, Chen WM, Akolkar B, Erlich HA, Hilner JE, Julier C, Nerup J, Nierras C, et al. Tests for genetic interactions in type 1 diabetes: linkage and stratification analyses of 4,422 affected sib-pairs. Diabetes. 2011;60(3):1030-40.

10. Concannon P, Gogolin-Ewens KJ, Hinds DA, Wapelhorst B, Morrison VA, Stirling B, Mitra M, Farmer J, Williams SR, Cox NJ, et al. A second-generation screen of the human genome for susceptibility to insulin-dependent diabetes mellitus. Nat Genet. 1998;19(3):292-6.

11. Einarsdottir E, Egerbladh I, Beckman L, Holmberg D, Escher SA. The genetic population structure of northern Sweden and its implications for mapping genetic diseases. Hereditas. 2007;144(5):171-80.

12. Humphreys K, Grankvist A, Leu M, Hall P, Liu J, Ripatti S, Rehnstrom K, Groop L, Klareskog L, Ding B, et al. The genetic structure of the Swedish population. PloS One. 2011;6(8):e22547.

13. Bittles $A H$, Egerbladh I. The influence of past endogamy and consanguinity on genetic disorders in northern Sweden. Annals of human genetics. 2005; 69(Pt 5):549-58.

14. Mayans S, Lackovic K, Nyholm C, Lindgren P, Ruikka K, Eliasson M, Cilio CM, Holmberg D. CT60 genotype does not affect CTLA-4 isoform expression despite association to T1D and AITD in northern Sweden. BMC Med Genet. 2007:8:3.

15. Einarsdottir E, Soderstrom I, Lofgren-Burstrom A, Haraldsson S, Nilsson-Ardnor S, Penha-Goncalves C, Lind L, Holmgren G, Holmberg M, Asplund K, et al. The CTLA4 region as a general autoimmunity factor: an extended pedigree provides evidence for synergy with the HLA locus in the etiology of type 1 diabetes mellitus, Hashimoto's thyroiditis and Graves' disease. Eur J Hum Genet. 2003; 11(1):81-4

16. Einarsdottir E, Mayans S, Ruikka K, Escher SA, Lindgren P, Ågren $\AA$, Eliasson M, Holmberg D. Linkage but Not Association of Calpain-10 to Type 2 Diabetes Replicated in Northern Sweden. Diabetes. 2006;55:1879.

17. Mayans S, Lackovic K, Lindgren P, Ruikka K, Agren A, Eliasson H, Holmberg D. TCF7L2 polymorphisms are associated with type 2 diabetes in northern Sweden. Eur J Hum Genet. 2007;15(3):342-6.
18. Nilsson-Ardnor S, Janunger T, Wiklund PG, Lackovic K, Nilsson AK, Lindgren P, Escher SA, Stegmayr B, Asplund K, Holmberg D. Genome-wide linkage scan of common stroke in families from northern Sweden. Stroke. 2007;38(1):34-40.

19. Wellcome Trust Case Control, C. Genome-wide association study of 14,000 cases of seven common diseases and 3,000 shared controls. Nature. 2007; 447(7145):661-78.

20. Burton PR, Clayton DG, Cardon LR, Craddock N, Deloukas P, Duncanson A, Kwiatkowski DP, McCarthy MI, Ouwehand WH, Samani NJ, et al. Association scan of 14,500 nonsynonymous SNPs in four diseases identifies autoimmunity variants. Nat Genet. 2007;39(11):1329-37.

21. Hakonarson H, Grant SF, Bradfield JP, Marchand L, Kim CE, Glessner JT, Grabs R, Casalunovo T, Taback SP, Frackelton EC, et al. A genome-wide association study identifies KIAA0350 as a type 1 diabetes gene. Nature. 2007;448(7153):591-4.

22. Smyth DJ, Cooper JD, Bailey R, Field S, Burren O, Smink LJ, Guja C, lonescu-Tirgoviste C, Widmer B, Dunger DB, et al. A genome-wide association study of nonsynonymous SNPs identifies a type 1 diabetes locus in the interferon-induced helicase (IFIH1) region. Nat Genet. 2006; 38(6):617-9.

23. Todd JA, Walker NM, Cooper JD, Smyth DJ, Downes K, Plagnol V, Bailey R, Nejentsev S, Field SF, Payne F, et al. Robust associations of four new chromosome regions from genome-wide analyses of type 1 diabetes. Nat Genet. 2007;39(7):857-64.

24. Barrett JC, Clayton DG, Concannon P, Akolkar B, Cooper JD, Erlich HA, Julier C, Morahan G, Nerup J, Nierras C, et al. Genome-wide association study and meta-analysis find that over 40 loci affect risk of type 1 diabetes. Nat Genet. 2009;41(6):703-7.

25. Bradfield JP, Qu HQ, Wang K, Zhang H, Sleiman PM, Kim CE, Mentch FD, Qiu H, Glessner JT, Thomas KA, et al. A genome-wide meta-analysis of six type 1 diabetes cohorts identifies multiple associated loci. PLoS Genet. 2011;7(9):e1002293

26. Hakonarson H, Qu HQ, Bradfield JP, Marchand L, Kim CE, Glessner JT, Grabs R, Casalunovo T, Taback SP, Frackelton EC, et al. A novel susceptibility locus for type 1 diabetes on Chr12q13 identified by a genome-wide association study. Diabetes. 2008;57(4):1143-6.

27. Baniyash M, Garcia-Morales P, Luong E, Samelson LE, Klausner RD. The T cell antigen receptor zeta chain is tyrosine phosphorylated upon activation. J Biol Chem. 1988;263(34):18225-30.

28. Samelson LE, Patel MD, Weissman AM, Harford JB, Klausner RD. Antigen activation of murine T-cells induces tyrosine phosphorylation of a polypeptide associated with the T-cell antigen receptor. Cell. 1986;46(7):1083-90.

29. Burn GL, Svensson L, Sanchez-Blanco C, Saini M, Cope AP. Why is PTPN22 a good candidate susceptibility gene for autoimmune disease? FEBS letters. 2011;585(23):3689-98.

30. Waterhouse P, Penninger JM, Timms E, Wakeham A, Shahinian A, Lee KP, Thompson CB, Griesser H, Mak TW. Lymphoproliferative disorders with early lethality in mice deficient in Ctla-4. Science. 1995:270(5238):985-8.

31. Tivol EA, Borriello F, Schweitzer AN, Lynch WP, Bluestone JA, Sharpe AH. Loss of CTLA-4 leads to massive lymphoproliferation and fatal multiorgan tissue destruction, revealing a critical negative regulatory role of CTLA-4. Immunity. 1995:3(5):541-7.

32. Yamanouchi J, Rainbow D, Serra P, Howlett S, Hunter K, Garner VE, Gonzalez-Munoz A, Clark J, Veijola R, Cubbon R, et al. Interleukin-2 gene variation impairs regulatory $T$ cell function and causes autoimmunity. Nature Genet. 2007;39(3):329-37.

33. Wellcome Trust Case Control C. Genome-wide association study of 14,000 cases of seven common diseases and 3,000 shared controls. Nature. 2007; 447(7145):661-78

34. Cooper JD, Simmonds MJ, Walker NM, Burren O, Brand OJ, Guo H, Wallace C, Stevens H, Coleman G, Wellcome Trust Case Control C, et al. Seven newly identified loci for autoimmune thyroid disease. Hum Mol Genet. 2012:21(23):5202-8.

35. Pundziute-Lycka A, Dahlquist G, Nystrom L, Arnqvist H, Bjork E, Blohme G, Bolinder J, Eriksson JW, Sundkvist G, Ostman J. The incidence of Type I diabetes has not increased but shifted to a younger age at diagnosis in the 0-34 years group in Sweden 1983-1998. Diabetologia. 2002;45(6):783-91

36. Abecasis GR, Cherny SS, Cookson WO, Cardon LR. Merlin-rapid analysis of dense genetic maps using sparse gene flow trees. Nat Genet. 2002;30(1):97-101.

37. Barrett JC, Fry B, Maller J, Daly MJ. Haploview: analysis and visualization of LD and haplotype maps. Bioinformatics. 2005;21(2):263-5. 
38. Cooper JD, Smyth DJ, Smiles AM, Plagnol V, Walker NM, Allen JE, Downes K, Barrett JC, Healy BC, Mychaleckyj JC, et al. Meta-analysis of genome-wide association study data identifies additional type 1 diabetes risk loci. Nat Genet. 2008:40(12):1399-401.

39. Luo L, Cai B, Liu F, Hu X, Wang L. Association of Protein Tyrosine Phosphatase Nonreceptor 22 (PTPN22) C1858T gene polymorphism with susceptibility to autoimmune thyroid diseases: a meta-analysis. Endocr J. 2012;59(5):439-45.

40. Sutherland A, Davies J, Owen CJ, Vaikkakara S, Walker C, Cheetham TD, James RA, Perros P, Donaldson PT, Cordell HJ, et al. Genomic polymorphism at the interferon-induced helicase (IFIH1) locus contributes to Graves' disease susceptibility. J Clin Endocrinol Metab. 2007;92(8):3338-41.

41. Petrone A, Giorgi G, Galgani A, Alemanno I, Corsello SM, Signore A, Di Mario U, Nistico L, Cascino I, Buzzetti R. CT60 single nucleotide polymorphisms of the cytotoxic T-lymphocyte-associated antigen-4 gene region is associated with Graves' disease in an Italian population. Thyroid. 2005;15(3):232-8.

42. Ting WH, Chien MN, Lo FS, Wang CH, Huang CY, Lin CL, Lin WS, Chang TY, Yang HW, Chen WF, et al. Association of Cytotoxic T-LymphocyteAssociated Protein 4 (CTLA4) Gene Polymorphisms with Autoimmune Thyroid Disease in Children and Adults: Case-Control Study. PloS One. 2016; 11(4):e0154394

43. Martinez A, Santiago JL, Cenit MC, de Las HV, de la Calle H, FernandezArquero M, Arroyo R, de la Concha EG, Urcelay E. IFIH1-GCA-KCNH7 locus: influence on multiple sclerosis risk. Eur J Hum Genet. 2008;16(7):861-4

44. Martinez A, Varade J, Lamas JR, Fernandez-Arquero M, Jover JA, de la Concha EG, Fernandez-Gutierrez B, Urcelay E. Association of the IFIH1-GCA$\mathrm{KCNH} 7$ chromosomal region with rheumatoid arthritis. Ann Rheum Dis. 2008;67(1):137-8.

45. Torres B, Aguilar F, Franco E, Sanchez E, Sanchez-Roman J, Jimenez Alonso J, Nunez-Roldan A, Martin J, Gonzalez-Escribano MF. Association of the CT60 marker of the CTLA4 gene with systemic lupus erythematosus. Arthritis Rheum. 2004;50(7):2211-5.

46. Prahalad S, Hansen S, Whiting A, Guthery SL, Clifford B, McNally B, Zeft AS, Bohnsack JF, Jorde LB. Variants in TNFAIP3, STAT4, and C12orf30 loci associated with multiple autoimmune diseases are also associated with juvenile idiopathic arthritis. Arthritis Rheum. 2009;60(7):2124-30.

47. Begovich AB, Carlton VE, Honigberg LA, Schrodi SJ, Chokkalingam AP, Alexander HC, Ardlie KG, Huang Q, Smith AM, Spoerke JM, et al. A missense single-nucleotide polymorphism in a gene encoding a protein tyrosine phosphatase (PTPN22) is associated with rheumatoid arthritis. Am J Hum Genet. 2004;75(2):330-7.

48. Hunt KA, Zhernakova A, Turner G, Heap GA, Franke L, Bruinenberg M, Romanos J, Dinesen LC, Ryan AW, Panesar D, et al. Newly identified genetic risk variants for celiac disease related to the immune response. Nat Genet. 2008;40(4):395-402.

49. Gorman CL, Russell Al, Zhang Z, Cunninghame Graham D, Cope AP, Vyse TJ. Polymorphisms in the CD3Z gene influence TCRzeta expression in systemic lupus erythematosus patients and healthy controls. J Immunol. 2008;180(2):1060-70.

50. Takeuchi T, Suzuki K. CD247 variants and single-nucleotide polymorphisms observed in systemic lupus erythematosus patients. Rheumatol. 2013;52(9): 1551-5.

51. Martins M, Williams AH, Comeau M, Marion M, Ziegler JT, Freedman BI, Merrill JT, Glenn SB, Kelly JA, Sivils KM, et al. Genetic association of CD247 (CD3zeta) with SLE in a large-scale multiethnic study. Genes Immun. 2015; 16(2):142-50.

52. Li R, Yang W, Zhang J, Hirankarn N, Pan HF, Mok CC, Chan TM, Wong RW, Mok MY, Lee KW, et al. Association of CD247 with systemic lupus erythematosus in Asian populations. Lupus. 2012;21(1):75-83.

53. Teruel M, McKinney C, Balsa A, Pascual-Salcedo D, Rodriguez-Rodriguez L, Ortiz AM, Gomez-Vaquero C, Gonzalez-Gay MA, Smith M, Witte T, et al. Association of CD247 polymorphisms with rheumatoid arthritis: a replication study and a meta-analysis. PloS One. 2013;8(7):e68295.

54. Radstake TR, Gorlova O, Rueda B, Martin JE, Alizadeh BZ, Palomino-Morales R, Coenen MJ, Vonk MC, Voskuyl AE, Schuerwegh AJ, et al. Genome-wide association study of systemic sclerosis identifies CD247 as a new susceptibility locus. Nat Genet. 2010;42(5):426-9.

55. Irving BA, Weiss A. The cytoplasmic domain of the $T$ cell receptor zeta chain is sufficient to couple to receptor-associated signal transduction pathways. Cell. 1991;64(5):891-901.

56. Love PE, Shores EW, Johnson MD, Tremblay ML, Lee EJ, Grinberg A, Huang SP, Singer A, Westphal $\mathrm{H}$. T cell development in mice that lack the zeta chain of the T cell antigen receptor complex. Science. 1993;261(5123):918-21.
57. Guy CS, Vignali DA. Organization of proximal signal initiation at the TCR:CD3 complex. Immunol Rev. 2009;232(1):7-21.

58. Love PE, Hayes SM. ITAM-mediated signaling by the T-cell antigen receptor. Cold Spring Harb Perspect Biol. 2010;2(6):a002485.

59. Holst J, Wang H, Eder KD, Workman CJ, Boyd KL, Baquet Z, Singh H, Forbes K, Chruscinski A, Smeyne R, et al. Scalable signaling mediated by T cell antigen receptor-CD3 ITAMs ensures effective negative selection and prevents autoimmunity. Nat Immunol. 2008;9(6):658-66.

60. Lundholm M, Mayans S, Motta V, Lofgren-Burstrom A, Danska J, Holmberg D. Variation in the $\mathrm{Cd} 3$ zeta $(\mathrm{Cd} 247)$ gene correlates with altered T cell activation and is associated with autoimmune diabetes. J Immunol. 2010; 184(10):5537-44.

61. Lundholm M, Motta V, Lofgren-Burstrom A, Duarte N, Bergman ML, Mayans S, Holmberg D. Defective induction of CTLA-4 in the NOD mouse is controlled by the NOD allele of Idd3/IL-2 and a novel locus (Ctex) telomeric on chromosome 1. Diabetes. 2006;55(2):538-44.

62. Nambiar MP, Enyedy EJ, Fisher CU, Krishnan S, Warke VG, Gilliland WR, Oglesby RJ, Tsokos GC. Abnormal expression of various molecular forms and distribution of $\mathrm{T}$ cell receptor zeta chain in patients with systemic lupus erythematosus. Arthritis Rheum. 2002;46(1):163-74.

63. Berg L, Ronnelid J, Klareskog L, Bucht A. Down-regulation of the T cell receptor CD3 zeta chain in rheumatoid arthritis (RA) and its influence on T cell responsiveness. Clin Exp Immunol. 2000;120(1):174-82.

\section{Submit your next manuscript to BioMed Central and we will help you at every step:}

- We accept pre-submission inquiries

- Our selector tool helps you to find the most relevant journal

- We provide round the clock customer support

- Convenient online submission

- Thorough peer review

- Inclusion in PubMed and all major indexing services

- Maximum visibility for your research

Submit your manuscript at www.biomedcentral.com/submit

) Biomed Central 